\title{
Moderating Role of Organizational Learning: Relationship Between Strategic Change and Performance
}

\author{
Baliratu Abubakar, Umar Abbas Ibrahim \\ Business Administration Department, Faculty of Management Science, Nile University of Nigeria, Abuja, Nigeria
}

Email address:

baliratuabubakar@yahoo.com (B. Abubakar), Abbas.ibrahim@nileuniversity.edu.ng (U. A. Ibrahim)

\section{To cite this article:}

Baliratu Abubakar, Umar Abbas Ibrahim. Moderating Role of Organizational Learning: Relationship Between Strategic Change and Performance. Science Journal of Business and Management. Vol. 9, No. 3, 2021, pp. 178-185. doi: 10.11648/j.sjbm.20210903.14

Received: June 17, 2021; Accepted: July 5, 2021; Published: July 15, 2021

\begin{abstract}
With several literature on strategic change, it is obvious that role of organizational learning in strategic change process is an aspect that is worth studying. The aim of this study is to examine the potential links between strategic change, organizational learning, and organizational performance. Based on the population of 22 Deposit Money Banks in Nigeria, a survey questionnaire was administered to 250 top manager, middle managers and front line employees of banks in Nigeria. In total, 154 responses were used after data processing. Linear Regression analysis was used to test the hypotheses in the study using Microsoft excel. The study revealed an insignificant moderating effect of organizational learning on the relationship between strategic change and organizational performance. All other relationships between constructs were found to be highly significant with a coefficient of determination value that denotes significant positive relationship between constructs. It is crucial for managers to be aware of their operating environment and the right type and suitable level of strategy to employ that fit changes in the environment to improve performance. Given the features of this paper, a pertinent literature and empirical study, thus, seeks for a future conceptual mode study to be carried out in service industries and in the context of developing countries. Hence this paper tries to explain the relationship that exist between strategic, performance and when organizational learning plays its role.
\end{abstract}

Keywords: Strategic Change, Organizational Performance, Organizational Learning, Deposit Money Banks, Operational Efficiency, Adaptiveness

\section{Introduction}

Few decades ago saw many companies build and applied business models that were sustainable and remained relevant for years without modification or any adjustment to these models [23]. In that era, $80 \%$ of publicly traded profitable businesses remained in the league of top performance for six years or more, where business survival in the 1970s was exclusively based on stability and building a strong competitive wall to entry [23]. However, same cannot be said for the businesses in today's world. It has thus become imperative for organizations to fully imbibe the change culture in order to create an improved organizational structure able to demonstrate continued value and relevance to its customers, to improve performance, achieve, maintain competitive advantage and it's overall survival in its business environment [17]. As a result, some organization have become skilled in putting in place strategies that will successfully adapt to uncertainty in the environment for their long term survival [23].

Strategic change is seen as a critical potent because it paves the way through which organizations can sustain their hold on stiff competitive and changes in the environment, which normally stands as threat between an organization and its successful performance [15]. Confronted with the fact that "business as usual" might not happen anytime soon after the emergence of COVID 19 pandemic in Nigeria, organizations are beginning to accept the present state of things as the new normal, having a paradigm shift from temporary fixes to implementing strategic changes for improved performance and their survival [21]. Although, most organizations can never be fully prepared for the shock the environment might bring, strategic change typically aim at getting organizations begin to expect the unexpected, bounce back quickly after a shock and transform disadvantages into opportunities [30]. However, strategies to enhance performance usually covers a 
large scope of changes in an organization that may likely to affect the working conditions, decision making and work related attitude within the organization [22]. Overall, strategic change is a "double- edge sword", since it may result to increased performance in the long run and decreased performance in the short term [16].

Of particular interest to this study is organizational learning as a moderating variable to the implementation of strategic change to improve performance. Organizational learning can span from employees of an organization learning within their corporate environment to customer learning how to better leverage services provided by an enterprise [5]. Organizational learning is responsible for bringing about flexibility in an organizational structure, processes and practices, which is essential in today's dynamic business environment [25].

The Nigeria Banking Industry plays an important role in the nation's economy, owning $34.2 \%$ of the entire equities market capitalization of the Nigeria Stock Exchange and contributes $3.6 \%$ to the country's GDP in the second quarter of 2020 representing a steady growth from the previous quarter [19]. Despite their significant importance to the nation's economy, they are not spared those forces that threaten their performance ranging from a lethargic economy, tough competition, poor service delivery to currency devaluation and other micro and macro challenges [19]. It is against the scenery that this study seeks to examine the function of organizational learning on the relationship between strategic change and performance in the context of Deposit Money Banks in Nigeria.

\subsection{Problem Statement}

It has become critical for organizations to take on strategic change initiatives to remain competitive, however, approximately $40 \%-70 \%$ of organizational change initiatives fail [28]. Failure to achieve set objective by most organizations including Deposit Money Banks in Nigeria can be attributed to but not restricted to inadequate change leadership skills, lack of resources, resistance to change, priority focus on system than people, inadequate support from leadership and poor planning among others [19]. From the tail end of 1990s up until now, Nigerian banks have bought into the idea of strategic change via business process re-engineering resulting to upsurge in merger and acquisition [19]. However, most of the banks began laying off employees as a measure to manage the change process, causing high staff turnover in the banking sector which in turn has its adverse effect on productivity. Kipesha and Koech [2020] ascribe failure in strategic change process to the inability of management to split between strategic planning and strategic thinking [8]. Adoption and sustainment of strategic change are long term investment; the greater the length of change the more the need for new resources and new capabilities building usually not bargained for by change drivers during a change effort [16].

Characterize by these uncertainties and ambiguity, strategic change drivers in most organizations lack the understanding of the different facet of strategic change initiative in the bid to improve performance and remain competitive [28]. As a result of this deficiency, organizations are rather confronted with huge losses in time and financial resources than achieving set objective. Also, employees often grow cynical after a failed change effort and hence getting their buy-in for a new process becomes difficult [29].

Most researchers have had difficulty harmonizing the role of strategic change and organizational performance; this could be attributed to insufficient empirical in this field [14]. Few studies that investigated strategic change and organizational performance in Nigeria have focused on the effect of mediating role of environmental dynamics [15], strategic change management on maritime crude oil transportation [18] and employees' behavioral attitude and firm performance of selected manufacturing firms [1]. This study intends to address this important gap by investigating Deposit Money Banks in Nigeria to ascertain the relationship between strategic change and performance in an organization and what role organizational learning plays in this relationship.

\subsection{Research Objectives}

The principal objective in carrying out this study is to probe the moderating role of organizational learning on the relationship between strategic change and performance in Deposit Money Banks in Nigeria. Other specific objectives are as follows;

i. To evaluate to what extent strategic change could translate to efficiency of operations in Deposit Money Banks in Nigeria.

ii. To access the intensity of strategic change on adaptiveness of Deposit Money banks in Nigeria.

iii. To ascertain the impact organizational learning on the relationship between strategic change and performance in Deposit Money Banks in Nigeria.

\subsection{Research Questions}

This study attempts to respond to research questions stated below;

i. To what extent does strategic change influence efficiency of operations in Deposit Money Banks?

ii. Does strategic change have a positive effect on adaptiveness in Deposit Money Banks in Nigeria?

iii.Can organizational learning posses a significant, positive effect on the strategic change - performance relationship in Deposit Money Banks in Nigeria?

\subsection{Research Hypotheses}

Hol strategic change has no significant, positive effect on efficiency of operations in Deposit Money Banks in Nigeria.

Ho2 strategic change does not positively influence adaptiveness in Deposit Money Banks in Nigeria.

Ho3 organizational learning does not positively and significantly influence the relationship between strategic change and performance in Deposit Money Banks in Nigeria. 


\section{Literature Review}

\subsection{The Concept of Strategic Change}

Strategic change can be define as putting in place new strategies which may disrupt the normal routines of the organization with the aim of moving the organization from where it is presently to a more desirable position [30]. Strategies to enhance performance usually covers a large scope of organizational modification that are likely to affect the working norms, decision making hierarchy and work related behaviors within the organization [21]. Any strategic change stands to reveal two possible outcome at the long run, a performance gain could be achieve in the long term and it could be detrimental to short term performance [16]. Nevertheless, organizations must learn to implement strategic change that suits their business environment to achieve high performance and maintain competitive advantage.

\subsubsection{Organizational Performance}

Performance can be described as the outcome of an organizational strategies and operations [17]. This study adopts Kipesha and Koech [2020] conceptualization of performance as i) efficiency of operation and ii) adaptiveness [8], this conceptualization will allow the researcher obtain a holistic view regarding quality of work, skills and knowledge of the performer, managerial role such as problem solving and planning, also, the flexibility and open mindedness of Deposit Money Banks in Nigeria in the context of change strategies adopted [6]. Organizational adaptiveness can be evident in an organization creativity, their problem solving solving ability and how innovative they can be, it creates value in a world filled with ambiguity and uncertainty [13]. Significant gain in performance can be achieve by using strategies to stream line processes that has the ability of enhancing operational efficiency.

\subsubsection{Organizational Learning}

Although just a little consensus surrounds the definition of organizational learning. Organizations are viewed as learning by encrypting logical thinking from history into routines that guide activity [12], which in turn suggests organizational learning is mundane process, relies on past events and focuses on target. In line with this view, this study defines organizational learning as a firms ability to unlearn obsolete ways of carrying out its business by developing, transferring and retaining knowledge within the organization that are sure to create and maintain competitive advantage [24]. This sort of learning is said to be a "generative and double-loop learning" aiming at changing the day to day activities of an organization [11]. In contrast, a more common type of organizational learning is an "adaptive, single-loop learning" that focuses more on basic amendment at the strategic levels [2].

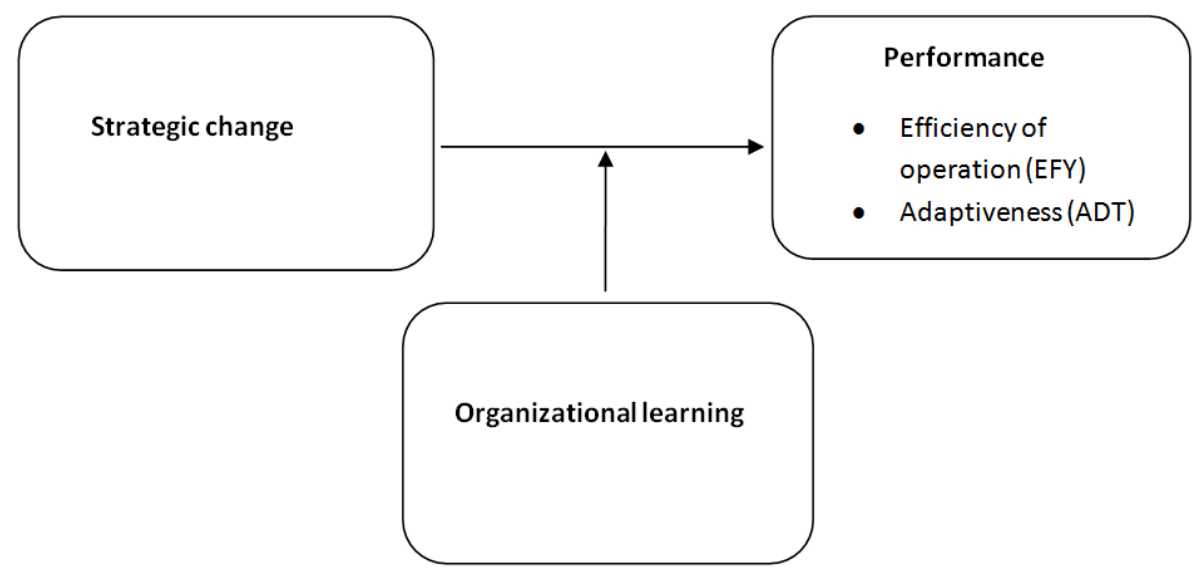

Figure 1. Conceptual Framework.

\subsection{Kotter's Change Model}

John Kotter, known for his change expertise brought about the 8 Step change Model which are building a sense of importance, creating powerful guiding alliance, coming up with a vision and a strategy, communicating the vision, removing impediments and empowering employees for action, creating short-term wins, consolidating gains and strengthening change by anchoring change in the culture [9]. Its principle aim was to better an organization's potential to move to a more desirable position and to enhance its possibilities of success.

Not so many change initiatives have come out victorious because victory is declared too early. Real change takes time, quick wins do happen but only at the beginning of the change process and is a prerequisite for what needs to be executed to achieve long-term change. Another critical factor for a successful change process is top management credibility [10]. According to Collins [2016], appropriate people management techniques attributes to 94 percent of highly successful change management programs [3]. Change management programs are crucial for organization overall liberation, survival and growth and a strategy that sees to the saturation and maturity levels in particular [20].

Critiques of Kotter's approach draws attention to the model inadequacy to account for the variability of the global economy, and that it is directed towards a single, straight line road map to change, rather than a cyclical one [7]. 


\subsection{Empirical Review}

Change is the only constant. It is very important for an organization to adopt new strategy every now and then to improve its performance [26]. Vithessonthi and Thoumrungroje [2011] in their studies on changing the narrative on poor firm performance using strategic change, a reversal strategy will be requires to improve performance; thus, a firm must find solution to the main problems responsible for the declining performance [25]. A second view of strategic change has centred on how organizational performance is maintained and improves using change strategies. This aspect identifies that firms can improve on performance if they persevere on the use of strategic change focusing on positioning their strategy, structure, and ideology with on-going changes in the business environment [18]. Hence, difference between these views is evident in timing i.e the first view, when performance is bad and the other has to do with maintaining and improving organizational performance.

Several studies on strategic management have suggested that top management team play a crucial role in strategicdecision making in turn strategic choices and this may have an impact on the usage of strategic change in an organization. Díaz-Fernández et al. [2020] investigated top management team (TMT) diversity and high performance among multinational high - technology companies in 8 countries USA, China, France, Germany, Canada, Italy, United Kingdom and Spain. Top management was conceptualized using five dimensions i) Functionality ii) Age iii) International experience iv) Industry and v) Education [4]. Simple ratios were calculated for these variables and Blau's index (1977) was applied to measure diversity. ROA was used to measure firm's performance. Data on TMT was collected via secondary information via website, yearbook, the specialist entrepreneurial journal and primary data from telephone and email interviews. Data on firm performance were obtained from financial reports of the companies. The data collected were analyzed using fuzzy-set qualitative comparative analysis and the results revealed that no TMT composition diversity leads to high firm performance, but instead that various solution in terms of TMT diversity antecedent are achieved.

Strategic change has also been investigated to improve performance. Mohammed [2019] investigated the relationship between strategic change and firm non-financial performance among money deposit banks in Nigeria [15]. Strategic change was measured using a 6 - item questionnaire while firm performance was measured using 8 - item questionnaire. Data was collected from managers of 22 main deposit money banks across the country. The data collected was analyzed using structural equation modelling and a positive significant relationship was revealed between construct.

Naranjo- Gil [2015] also examined the effect of strategic change on long and short term non- financial performance [16], carrying out a survey base study on Spanish hospitals.
Four key dimensions i) advertising intensity ii) research and development intensity iii) asset intensity iv) production expenditure was used to measure strategic change. Efficiency of the use of health resources was used to measure performance. The study adopted a longitudinal survey research design and data obtained was analyzed using Partial Least Square technique PLS. The result of the study revealed a negative and significant relationship between strategic change and short term performance and a positive, significant relationship between strategic change and long term performance.

Thoumrungroje [2015] assessed the moderating role of organizational learning on marketing strategic change and business performance among service oriented and manufacturing firms in Bangkok, Thailand [24]. Marketing strategic change (MSC) was measured using a 6-item 7-point scale $(1=$ very few changes; $7=$ very frequent changes $)$, three dimensions of Organizational learning (OGL) was adopted i) commitment to learning ii) shared vision, and iii) open-mindedness measured using an 18-item 7 point Likert scale. Business performance was assessed in terms of adaptiveness (ADP) and effectiveness (EFT) both of which was measured using a 3- item 7-point scale with scales anchored with 1 as "very poor" and 7 as "excellent". 95 responses were collected from 105 SBU's and analyzed using path analysis. The result revealed MSC to both ADP and EFT were positive and significant $(\gamma=2.082, \mathrm{p}=.026$ and $\gamma=$ $2.318, \mathrm{p}=.013$ ) and OGL - ADP and OGL - EFT paths show positive and significant relationships in the full sample $(\gamma=$ $1.182, \mathrm{p}=.000$ and $\gamma=1.142, \mathrm{p}=.000)$.

\section{Methodology}

A cross - sectional survey research design. Specifically, to address the problem of uncertainties surrounding the effect strategic change on organizational performance in money deposit banks in Nigeria and how it affects their stability in highly uncertain environment, hence, the justification for adopting the survey research design. The research design was suitable because it gives room for the collection, description, analysis and interpretation of data clearly and relevant to this study.

There are 22 main deposit money banks in Nigeria according to the updated list of Deposit Money Banks (DMBs) information released by the Central Bank of Nigeria (CBN, 2017), however, the Securities Exchange Commission (SEC) website shows that only sixteen (16) of these banks are listed. This study population covers the entire listed Money Deposit Banks in Nigeria.

A sample size used in this study encompass the entire population size due to it's limited number. A total of 250 questionnaires designed on a 5 point Likert scale $(1=$ strongly agree; $5=$ strongly disagree) were self-administered to senior management, middle management and frontline staff of the banks with the help of a trained research assistant. 154 completed questionnaires was retrieved representing $62 \%$ of questionnaire administered and use as the final sample size. 
Linear Regression analysis using microsoft excel was used to ascertain the relationship between variables base on the formulated hypotheses o. The hypothesis is tested using Pvalue from the regression model set against significance level 0.05 . Figure 1 below presents the association between strategic change and efficiency of operations.

The statistical of significant of $\mathrm{P}$-value 0.017 shows that efficiency of operations is positively and significantly influenced by strategic change. This finding is consistent with the findings of Kipesha and Koech, 2020. Hence the null hypothesis, No significant relationship between Strategic change and efficiency of operations is rejected. The Rsquare is 0.884114606 which suggest an $88 \%$ change in efficiency of operation is predicted by strategic change.

\begin{tabular}{|c|c|c|c|c|c|c|c|c|}
\hline \multicolumn{9}{|l|}{ SUMMARY OUTPUT } \\
\hline \multicolumn{9}{|c|}{ Regression Statistics } \\
\hline Multiple R & 0.940273687 & & & & & & & \\
\hline R Square & 0.884114606 & & & & & & & \\
\hline Adjusted R Square & 0.845486142 & & & & & & & \\
\hline Standard Error & 0.110904174 & & & & & & & \\
\hline Observations & 5 & & & & & & & \\
\hline \multicolumn{9}{|l|}{ ANOVA } \\
\hline & $d f$ & SS & MS & $F$ & Significance $F$ & & & \\
\hline Regression & 1 & 0.281511993 & 0.281512 & 22.8876456 & 0.01736412 & & & \\
\hline Residual & 3 & 0.036899207 & 0.0122997 & & & & & \\
\hline \multirow[t]{2}{*}{ Total } & 4 & 0.3184112 & & & & & & \\
\hline & Coefficients & Standard Error & tStat & $P$-value & Lower 95\% & Upper 95\% & Lower $95.0 \%$ & Upper $95.0 \%$ \\
\hline Intercept & -0.06977242 & 0.075035205 & -0.9298625 & 0.42103214 & -0.3085679 & 0.169023091 & -0.308567931 & 0.16902309 \\
\hline $\mathrm{SC}$ & 1.349561221 & 0.282092819 & 4.7841034 & 0.01736412 & 0.45181597 & 2.247306469 & 0.451815972 & 2.24730647 \\
\hline
\end{tabular}

Figure 2. Relationship between strategic change and efficiency of operations.

Figure 3 displays the association between strategic change and organizational adaptiveness with a significant P- value 0.013 which suggest that organizational adaptiveness is positively and strongly influenced by strategic change giving to to the rejection of null hypothesis which states that no significant relationship between strategic change and adaptiveness. The R-square 0.9000167 suggest an $90 \%$ change in adaptiveness is predicted by strategic change.

\begin{tabular}{|c|c|c|c|c|c|c|c|c|}
\hline SUMMARY OUTPUT & & & & & & & & \\
\hline \multicolumn{2}{|c|}{ Regression Statistics } & & & & & & & \\
\hline Multiple R & 0.9817865 & & & & & & & \\
\hline R Square & 0.9639047 & & & & & & & \\
\hline Adjusted R Square & 0.951873 & & & & & & & \\
\hline Standard Error & 0.0618955 & & & & & & & \\
\hline Observations & 5 & & & & & & & \\
\hline \multirow[t]{2}{*}{ ANOVA } & & & & & & & & \\
\hline & $d f$ & SS & $M S$ & $F$ & Significance $F$ & & & \\
\hline Regression & 1 & 0.3069181 & 0.3069181 & 80.113345 & 0.00294262 & & & \\
\hline Residual & 3 & 0.0114931 & 0.003831 & & & & & \\
\hline \multirow[t]{2}{*}{ Total } & 4 & 0.3184112 & & & & & & \\
\hline & Coefficients & itandard Erro & t Stat & $P$-value & Lower 95\% & Upper 95\% & Lower $95.0 \%$ & Upper $95.0 \%$ \\
\hline Intercept & -0.1545455 & 0.048288 & -3.2004961 & 0.0493131 & -0.30821943 & -0.0008716 & -0.3082194 & -0.0008716 \\
\hline SC & 1.7760557 & 0.1984285 & 8.9506058 & 0.0029426 & 1.14456751 & 2.4075439 & 1.1445675 & 2.4075439 \\
\hline
\end{tabular}

Figure 3. Relationship with strategic change and organizational adaptiveness.

Figure 4 expresses the effect of organizational learning on relationship between strategic change and performance. The null hypothesis," no significant positive effect of organizational learning on the relationship between strategic change and performance " is accepted. A P- value of 0.14 denotes an insignificant relationship. it can be concluded that 
organizational learning weakens the effect strategic change on performance both in terms of efficiency of operations and adaptiveness. This result is consistent to prior studies Thourmungroje, 2015.

\begin{tabular}{|c|c|c|c|c|c|c|c|c|}
\hline \multicolumn{9}{|l|}{ SUMMARY OUTPUT } \\
\hline \multicolumn{9}{|c|}{ Regression Statistics } \\
\hline Multiple R & 0.9821863 & & & & & & & \\
\hline Adjusted R Square & 0.9293799 & & & & & & & \\
\hline Standard Error & 0.0749771 & & & & & & & \\
\hline Observations & 5 & & & & & & & \\
\hline \multicolumn{9}{|l|}{ ANOVA } \\
\hline & $d f$ & SS & MS & $F$ & Significance $F$ & & & \\
\hline Regression & 2 & 0.3071681 & 0.153584 & 27.32054632 & 0.035310053 & & & \\
\hline Residual & 2 & 0.0112431 & 0.0056216 & & & & & \\
\hline Total & 4 & 0.3184112 & & & & & & \\
\hline X Variable 1 & 1.6239658 & 0.7601687 & 2.1363228 & 0.166152321 & -1.646776186 & 4.89470775 & -1.646776186 & 4.894707746 \\
\hline X Variable 2 & 0.1271961 & 0.603127 & 0.2108945 & 0.852506073 & -2.467849836 & 2.72224213 & -2.467849836 & 2.722242132 \\
\hline
\end{tabular}

Figure 4. Organizational learning on relationship between strategic change and performance.

\section{Discussion}

This section speaks to the analyses of the research questions.

RQ1 To what extent does strategic change influence efficiency of operations in Deposit Money Banks?

Findings from this study as illustrated in Figure 1 showed that strategic change has a significant, positive impact on efficiency of operations in Deposit Money Banks in Nigeria. The result agrees with several empirical studies Kipesha and Koech, 2020, Kamau, 2013. Prior studies have looked at the effect of corporate strategy and business-level strategy on organizational efficiency in the events of strategic change in an organization Nitin (2015), Tsuma (2017) where both negative and positive outcomes have evolved without considering moderating or mediating variables such as organizational learning. This study has also revealed that despite the unstable economy and highly dynamic environment in which these banks find themselves, most of them do carry out a sufficient number of change strategy to combat both internal and external changes and improve their efficiency of operations.

QR2 Does strategic change have a positive on adaptiveness in Deposit Money Banks in Nigeria?

Outcome of this study has also revealed that strategic change to a great extent influence an organizational adaptiveness to its ever changing business environment, this finding is also consistent with the findings of Thoumrungroje (2015). Strategic change is seen as a critical potent because it paves the way through which an organization adapts to variability in it's environment which normally pose threats to their successful performance [27].

RQ3 Can organizational learning have a significant effect on the relationship between strategic change and performance in Deposit Money Banks in Nigeria?

The results revealed a insignificant, negative moderating role of organizational learning on strategic change performance relationship. Inconsistent with the conventional belief that organizational learning enables firms to carry out strategic changes successfully and result in desired performance. Where generative or double-loop learning is adopted by an organization at strategic implementation level, this may prove to be detrimental to the strategic change performance relationship. This result goes further to emphasizes the great importance of a good fit between the

type of learning and strategic changes needed for the organization to realize desired goal.

\section{Conclusion}

This paper assessed the relationship between strategic and organizational performance of Deposit Money Banks in Nigeria, where performance was represented by 2 indicators; efficiency of operations and adaptiveness of an organization to it's environment. Also assessed is the moderating effect of organizational learning on strategic change - performance relationship. They following conclusions are drawn;

The pervasiveness of dynamism of today's business environment is at a pace greater than ever before. To improve efficiency, organizations must identify skills gaps in operations before embarking on any strategic change implementation. This study revealed a significant positive relationship between strategic change and efficiency in operation, this may be due to the on going COVID-19 pandemic have forced most organizations to devise strategies to deal with short term and significant uncertainty to survive.

To have a competitive advantage and perhaps even survive in today's' business environment requires consistent, future focused activities that will permit organizations to plan and adapt to changes and uncertainty that may come up. Business termed as successful today will be those that are proactive, intentional and strategic about adapting well to changes to 
both their internal and external environment. The banks in this study showed a great deal of adapting well to changes in their environment.

This study is packed full with insights as to the moderating role of organizational learning on and its extent of association on strategic change and organizational performance, also revealing the need to imbibe the right sort learning at the right time as an important factor for strategic change and organizational performance. The end result of this study revealed an insignificant, negative role of organizational learning to the relationship between strategic change and organizational performance.

\section{Recommendation}

Given the conclusion above, the study recommend the following;

Improving operational efficiency is non-negotiable for the success of all businesses. Technology is at the heart of changing landscape. Technology powers communication, marketing, processes, shapes banking products and interaction with customers. Deposit money banks in Nigeria should invest in technology to improve efficiency and satisfy customer's needs.

The banking industry is a highly regulated industry prone to policy change and may undergo cataclysmic upheaval, top management team in the bank must be proactive in understanding their business environment, put in place future focus activities that will allow them adapt well to changes in their environment.

The requirement of strategic change may differ depending on whether the organization is manufacturing, construction or service organization. As an alternative to focusing on direct relationship, banks may also focus on organizational learning as a mediator and its operating environment that positively moderates the effects of strategic change on performance.

\section{References}

[1] Adeniji, C., Adeyeye, O., Iyiola, O., Olokundun, M., Motilewa, D., Ibidunni, S., \& Akinbode, M. (2018). Data on strategic change on employees' behavioural attitude and firm performance of selected manufacturing firms in Nigeria. Data in brief, 18, 15511555. https://doi.org/10.1016/j.dib.2018.04.032

[2] Azadegan, A., Srinivasan, R., Blome, C., \& Tajeddini, K. (2019). Learning from near-miss events: An organizational learning perspective on supply chain disruption response. International Journal of Production Economics, 216, 215-226.

[3] Collins, F (2016). Prosci Expanding Change Management Opportunities to Georgia. https://www.prnewswire.com/newsreleases/prosci-expanding-change-management-opportunitiesto-georgia-300325090.htm

[4] Díaz-Fernández, M. C., González-Rodríguez, M. R., \& Simonetti, B. (2020). Top management team diversity and high performance: An integrative approach based on upper echelons and complexity theory. European Management Journal, 38 (1), 157- 168. doi.org/10.1016/j.emj.2019.06.006
[5] Huprich, J. (2021). Forget learning style your organizational leraning strategy should be based on science. $\mathrm{https}$ ://news.elearninginside.com/forget-learning-styles-yourorganizational-learning-strategy-should-be-based-on-science/

[6] Jenatabadi, H. S. (2015). An Overview of OrganizationalPerformance Index: Definitions and Measurements. DOI: 10.13140/RG.2.1.4298.3849.

[7] Kazmi, S. A. Z., \& Naarananoja, M. (2013). Collection ofchange management models-an opportunity to make the best choice from the various organizational transformational techniques. GSTF Business Review (GBR), 2 (4), 44.

[8] Kipesha, E. N \& Koech, P. (2020). Effect of Strategic Change Management on Performance Of Selected Government Owned Entities in Mombasa County. International journal of advanced research and review, 5 (4), 1-19.

[9] Kotter, J. P. (1995). "Leading change: why transformation efforts fail". Harvard Business Review, 73 (2), 59-67.

[10] Kraatz, M. S. and Zajac, E. J. (2001).” How organizational resources affect strategic change and performance in turbulent environment: theory and evidence"Organizational Science. 85 (5), 632 - 657.

[11] Kumar, M., \& Misra, M. (2020). Evaluating the effects of CRM practices on organizational learning, its antecedents and level of customer satisfaction. Journal of Business \& Industrial Marketing. 36 (1), 164-176. doi.org/10.1108/JBIM11-2019-0502.

[12] Levitt, B. and March, J. G. (1988), "Organizational learning", Annual Review of Sociology, Vol. 14 No. 1, pp. 319-340.

[13] McGregor, L. \& Doshi, N. (2017, October 10) There are two types of performance but most organizations only focus on one. Hbr.org/2017/10/There- are- two -types- of- performancebut most -organizations -only- focus- on -one.

[14] Murschetz, P. C., Omidi, A., Oliver, J. J., Saraji, M. K., \& Javed, S. (2020). Dynamic capabilities in media management research. A literature review. Journal of Strategy and Management, 13 (2), 278-296. doi.org/10.1108/JSMA-01-2019-0010.

[15] Mohammad, H. I. (2019). Mediating effect of organizational learning and moderating role of environmental dynamism on the relationship between strategic change and firm performance. Journal of Strategy and Management, 20 (2), 275-297. doi.org/10.1108/JSMA-07-2018-0064

[16] Naranjo-Gil, D. (2015). The role of top management teams in hospitals facing strategic change: effects on performance. International Journal of Healthcare Management, 8 (1), 3441.doi.org/10.1179/2047971914Y.0000000078.

[17] Obonyo, E. S., \& Kerongo, F. (2015). Factors affecting strategic change management and the performance of commercial banks in Kenya: A case study of Kenya commercial bank in Nairobi region. European Journal of Business and Management, 7 (15), 109-117.

[18] Onugha, P., \& Onuoha, B. C. (2019). Change management and organizational effectiveness in nigeria maritime industry. Change, 5 (4).

[19] Oyekanmi, S (2020). Nigeria @ 60: The Banking Sector and the Nigerian economy. https://nairametrics.com/2020/10/01/nigeria60-the-banking-sector-and-the-nigerian-economy/ 
[20] Rajan, R. \& Ganesan, R. (2017). A Critical Analysis ofJohn P. Kotter's Change Management Framework. Asian journal of Research in Business Economics and Management. 7 (7), 181201.

[21] Schmidt, E., Groeneveld, S., \& Van de Walle, S. (2017). A change management perspective on public sector cutback management: towards a framework for analysis. Public Management Review, 19 (10), 1538-1555.

[22] Solinger, O. N., Joireman, J., Vantilborgh, T., \& Balliet, D. P. (2021). Change in Unit-Level Job Attitudes Following Strategic Interventions: A Meta-Analysis of Longitudinal Studies. Journal of Organizational Behavior. https://doi.org/10.1002/job.2523

[23] Teece, D. J., Raspin, P. G., \& Cox, D. R. (2020). Plotting strategy in a dynamic world. MIT Sloan Management Review, $62(1), 28-33$

[24] Thoumrungroje, A. (2015). The moderating roles of organizational learning and strategic flexibility on marketing strategic change and business performance: evidence from firms in Thailand. In International Marketing in the Fast Changing World, 26, 179-198. doi.org/10.1108/S1474797920150000026009

[25] Vithessonthi, C., \& Thoumrungroje, A. (2011). Strategic change and firm performance: The moderating effect of organizational learning. Journal of Asia Business Studies, 5 (2), 194210.

[26] Wei, Z. and Zhang, L. (2020), "How to perform strategic change? A strategy as practice perspective", Chinese Management Studies, 14 (3), 811-832. doi.org/10.1108/CMS04-2019-0140

[27] Yockelson, A. G. (2020). Examining the CEO's impact on strategic changes in technology organizations (Doctoral dissertation).

[28] Yue, C. A., Men, L. R., \& Ferguson, M. A. (2019). Bridging transformational leadership, transparent communication, and employee openness to change: The mediating role of trust. Public relations review, 45 (3), 101779.

[29] Zajac, E. J., Kraatz, M. S. and Bresser, R. K. F. (2000). "Modeling the dynamics of strategic fit: a normative approach to strategic change". Strategic Management Journal, 21 (4), 429-453.

[30] Zhang, C. (2021, May). Factors Influencing Strategic Change of New Energy Enterprises: An Analysis Based on Time Perspective. Earth and Environmental Science, 769 (4) 042031. doi: 10.1088/1755-1315/769/4/042031. 